УДК: 78.071.1.001.1 (470) : [780.616.432:785.6] “19”

DOI: https://doi.org/10.33643/kmus.2019.59.09

Анна Горобец,

аспирантка кафедры теории и истории культурь Национальной музыкальной академии Украины им. П. И. Чайковского https://orcid.org/0000-0002-6699-0583 hannahorobetsmusic@gmail.com

Hanna Horobets, Postgraduate at the Department of Theory and History of Culture, Ukrainian National Tchaikovsky Academy of Music https://orcid.org/0000-0002-6699-0583 hannahorobetsmusic@gmail.com

\title{
ВТОРОЙ ФОРТЕПИАННЫЙ КОНЦЕРТ СЕРГЕЯ ПРОКОФЬЕВА: К ПРОБЛЕМЕ ОБРАЗНО-СМЫСЛОВОЙ МНОГОЗНАЧНОСТИ ТЕКСТА
}

Статья посвящена исследованию специфики художественного замысла Фортепианного концерта № 2 (1913 г.) С. С. Прокофьева и разбору образно обоснованных исполнительских версий сочинения. С этой точки зрения рассмотрены четыре концептуально контрастные версии. Солисты: Н. Петров, В. Ашкенази, Ю. Ванг, Б. Гилтбург. Основное содержание исследования составляет анализ биографического контекста создания концерта, его формы, драматургии, жанровых основ тематизма, семантики отдельных элементов тем, а также реализации музыкального текста пианистами. Результаты работы позволили найти новые смыслы, скрытые в нотном тексте, и ресурсы для создания контрастных концепций концерта.

Ключевые слова: фортепианный концерт, пианизм Прокофьева, проблема многозначности текста, жанрово-интонационные истоки.

Horobets Hanna. Piano concerto № 2 by Sergey Prokofiev: multiple images and meanings in its music. This paper discusses the issue of multiple images and meanings in the music of the Piano Concerto № 2 by Prokofiev (1913). The scientific novelty and relevance of the subject are in the perspective through which the Concerto is examined: its music is analyzed applying stylistic analysis, figuring out the genre and intonation origins of its themes. The analysis is aimed at determining the important points of the dramatic line that define the imagery of the whole, as well as at explaining the essence of several conceptions of performing the Concerto created over four and a half decades (from 1975 to 2017). The methods of the theory of interpretation by V. Moskalenko, as well as some theses of monographs and works dedicated to the study of Prokofiev's 
style (by I. Martynov, I. Nestieva, V. Delson, L. Gakkel, T. Safonova, etc.) are at the theoretical and methodological foundation of the study. The applied methods are based on: the study of Prokofiev's epistolary works in order to understand the essence of the composer's conception of the Concerto and his thoughts regarding the performance of his compositions; the analysis of the memoirs of performers about S. Prokofiev (S. Richter, H. Neuhaus, A. Schnittke); the examining of the form and dramatic line of the Concerto in order to determine its thematic structure and semantics of its elements; interviews with teachers of piano, musicians, and music lovers; the analysis of a large number of performing versions in order to select the most contrasting and artistically convincing ones; the author's own analysis of the Concerto over the ten-year period. The aim of the paper is to study the distinctive characteristics of the artistic conception of Prokofiev's Piano Concerto № 2 and analyze its contrasting performing versions. From this perspective, four distinctly different performing concepts of Nikolai Petrov, Vladimir Ashkenazy, Yuja Wang, and Boris Giltburg are examined. Conclusions. The music of Prokofiev's Piano Concerto № 2 is full of allusions not only to stylistic layers distant in time (L. Beethoven, F. Liszt), but also to the contemporary music; there are Romantic allusions to the music of Scriabin, Debussy and Rachmaninoff. The genre basis of the Concerto's themes is one of the most important dramaturgical means: march, scherzo, dance, lullaby; it includes symbols associated not only with individual national traditions, but also with the embodiment of the idea of mass character and scale of action. Pianists, relying on their own understanding of Prokofiev's conception, created individualized performing concepts, emphasizing in the Concerto its lyrical, dramatic, romantic, virtuoso, tragic, fantasy, or philosophical characteristics. This demonstrates the versatility of the images of Prokofiev's work, the variety of its meanings, and the potential to discover new artistic facets of the Concerto.

Key words: piano concerto, Prokofiev's pianism, the issue of multiple meanings of the music, origins of genre and intonation.

Горобець Ганна. Другий фортепіанний концерт Сергія Прокоф'єва: проблема образно-смислової багатозначності тексту. Статтю присвячено питанню багатозначності музичного тексту Фортепіанного концерту № 2 (1913 р.) С. С. Прокоф'єва. Наукова новизна та актуальність теми полягає у ракурсі дослідження концерту: розгляді музичного тексту 3 використанням стильового аналізу та визначенням жанрово-інтонаційних витоків тематизму. Аналіз спрямовано на встановлення важливих моментів драматургї̈, які визначають образне наповнення цілого, а також на обгрунтування сутності декількох виконавських концепцій, створених 
протягом 45 років (1975-2017 рр.). Основою теоретичної та методологічної бази стали методика теорії інтерпретації В. Москаленка, положення в монографіях і роботах, присвячених дослідженню стилю Прокоф'єва (І. Мартинов, І. Нєстьєва, В. Дельсон, Л. Гаккель, Т. Сафонова та інші). Формуванню методики дослідження послужили: вивчення епістолярної творчості Прокоф'єва - для розуміння суті задуму концерту та думки композитора щодо виконання власних творів; аналіз спогадів виконавців про Прокоф'єва (С. Ріхтер, Г. Нейгауз, А. Шнітке); розгляд форми і драматургії концерту 3 визначенням структури тематизму та семантики окремих його елементів; інтерв'ювання викладачів гри на фортепіано, музикантів, аматорів; аналіз великої кількості виконавських версій, відбір найбільш контрастних і переконливих з них; власний аналіз концерту протягом 10 років.

Mema cmammi - дослідити специфіку художнього задуму Фортепіанного концерту № 2 С. Прокоф'єва та проаналізувати контрастні виконавські версії твору. 3 цієї точки зору розглянуто чотири відмінні концепції: Миколи Петрова, Володимира Ашкеназі, Юджі Ванг, Бориса Гілтбурга.

Висновки. Музичний текст Фортепіанного концерту № 2 С. Прокоф'єва насичений алюзіями не тільки до віддалених у часі стильових пластів (Л. Бетховен, Ф. Ліст), але й до музики сучасності - це романтичні алюзії до музики Скрябіна, Дебюссі, колокольних образів Рахманінова. Жанрова основа тематизму - один із найважливіших драматургічних засобів в концерті: марш, скерцо, танець, колискова. Вони включають в себе символіку, пов'язану не тільки зі звертанням до окремих національних традицій, але і з втіленням ідеї масовості, масштабності дії. Піаністи, спираючись на власне розуміння задуму Прокоф'єва, створюють індивідуалізовані концепції, підсилюючи в концерті лірико-драматичне, романтично-віртуозне, трагедійне, фантазійне чи філософське начало. Це свідчить про багатогранність образів прокоф'євського твору, різноманіття смислів, можливість прочитання та пошуку нових художніх граней концерту.

Ключові слова: фортепіанний концерт, піанізм Прокоф'єва, проблема багатозначності тексту, жанрово-інтонаційні витоки.

Мое творчество вне времени и пространства. С. С. Прокофьев

«Я всегда чувствовал потребность самостоятельного мышления и следования своим собственным идеям. <..> Во всем, что я пишу, я придерживаюсь двух главных принципов - это ясность в выявлении моих 
идей и лаконизм, избегая всего лишнего в их выражении» [20, с. 600], - эти слова С. Прокофьева способны объяснить многое в его новаторском мышлении, неординарном таланте, эмоциональном напоре и ясной, жесткой логике мышления.

Существование разных, часто образно контрастных исполнительских версий его произведений подтверждает многозначность и глубину, заложенные в них автором. С обращением к одному из наиболее ярких сочинений фортепианной литературы связана актуальность темы. Научная новизна заключается в ракурсе исследования концерта: рассмотрении музыкального текста с применением принципов стилевого анализа и определением жанрово-интонационных истоков тематизма. Анализ направлен на установление драматургически значимых моментов, которые определяют образное наполнение целого, а также на обоснование сути нескольких исполнительских концепций, созданных на протяжении 45 лет (1975-2017 гг.).

Личность Прокофьева, соединяя в себе, казалось бы, противоположные качества (бунтарь - и приверженец традиций, композитор светлого мироощущения, часто скептик - и художник, умеющий выразить бесконечную безысходность и трагизм, лирик - и жесткий рационалист), продолжает оставаться загадкой, раскрывающейся во времени. Композитор предпочитал не давать комментарии к своим сочинениям: расшифровка заключенных в них замыслов, стремление создать собственную концепцию концерта, нестандартного по композиции, непростого драматургически и многогранного образно, становятся своеобразной сверхзадачей для современных музыкантов.

Цель статьи: исследовать специфику художественного замысла Фортепианного концерта № 2 С. Прокофьева и проанализировать образно обоснованные, контрастные исполнительские версии сочинения. С этой точки зрения рассмотрены четыре концептуальные версии. Солисты: Николай Петров ${ }^{1}$, Владимир Ашкенази ${ }^{2}$ Юджа Ванг ${ }^{3}$, Борис Гилтбург ${ }^{1}$ Они выбраны, поскольку:

\footnotetext{
${ }^{1}$ Дирижер Юрий Темирканов (Государственный академический симфонический оркестр СССР, Большой зал Московской консерватории, Москва, 1985 г.) [Электронный pecypc]. URL: https://www.youtube.com/watch?v=GsX8r9v7Vfc (дата обращения: 23.03.2019).

2 Дирижер Андре Превин (London Symphony Orchestra Direction, студийная запись 1974-75 гг., London Label: Decca [Электронный pecypc]. URL: https://www.youtube.com/watch?v=sdkJlufLOwg (дата обращения: 23.03.2019).

${ }^{3}$ Дирижер Paavo Järvi (Берлинская филармония, 2017 г.) [Электронный ресурc]. URL: https://www.youtube.com/watch?v=vB6Hz-VQSKw (дата обращения: 23.03.2019).
} 
- позволяют охватить временной диапазон от середины 70-х годов до нынешних лет;

- представляют прославленных пианистов старой школы в сопоставлении с музыкантами нового поколения;

- позволяют сопоставить концепции разного уровня профессиональной и человеческой зрелости;

- презентуют блестящий технический уровень и высокую степень образно-эмоционального проникновения в композиторский замысел;

- демонстрируют различные варианты трактовки смысло-образности тематизма концерта - концептуально различные версии образносодержательного уровня сочинения С. Прокофьева;

- являются индивидуализированными, художественно убедительными и завершенными в трактовке композиторского замысла.

Неоднозначность трактовки произведений Прокофьева подтверждается не только разбросом музыковедческих мнений по поводу смысло-образности тематизма и замысла концерта (о нем писали И. Мартынов, Л. Гаккель, И. Нестьева, В. Дельсон и другие), но и немалым количеством концептуально разных исполнительских версий: от лирикодраматических - с эмоционально-взволнованным, патетичным, жизнеутверждающим итогом финала - до обостренно-драматических, философских, с трагедийным исходом.

В основе теоретической и методологической базы - методика теории интерпретации В. Москаленко, положения монографий и работ, посвященных исследованию стиля С. Прокофьева (И. Мартынов, И. Нестьева, В. Дельсон, Л. Гаккель, Т. Сафонова и другие). Формированию методики исследования послужили: изучение эпистолярного творчества Прокофьева - для понимания сущности замысла концерта и мнения композитора о том, как нужно исполнять его произведения; анализ воспоминаний исполнителей о Прокофьеве (С. Рихтер, Г. Нейгауз, А. Шнитке); рассмотрение формы и драматургии концерта с выявлением структуры тематизма, семантики отдельных его элементов; интервьюирование преподавателей игры на фортепиано, музыкантов, аматоров; анализ множества исполнительских версий, отбор наиболее контрастных и убедительных; собственный анализ концерта на протяжении 10 лет.

${ }^{1}$ Дирижер Edode Waart (Брюсель, Centre for the Fine Arts, die Filharmonie - Royal Flemish Philharmonic, закрытие конкурса Королевы Елизаветы, 2013) [Электронный pecypc]. URL: https://www.youtube.com/watch?v=FNObak61O0c (дата обращения: 23.03.2019). 


\section{История создания}

Второй концерт для фортепиано с оркестром g-moll Сергей Прокофьев написал в 1913 г. (вторую редакцию - в 1923 г., после потери партитуры в годы революции) - то есть в ранний и зрелый периоды: смыслы, близкие студенту консерватории, соединились с мастерством зрелого композитора, который к 1923 г. создал фортепианный концерт № 3 (1921 г.), четыре оперы ${ }^{1}$, балет ${ }^{2}$, две симфонии, четыре фортепианные сонаты. Посвящение трагически ушедшему другу, Максимилиану Шмидтгофу, - один из факторов подтверждения не только лирической, но и драматической образности Концерта.

Прокофьев почти не давал комментариев к сочинениям: «Совершенно не убежден <..>, что, сообщив слушателям о своих принципах, композитор может считать, что он тем самым полностью рассказал о своих намерениях...», - утверждал он [20, с. 43]. Поэтому расшифровка заключенных в тексте смыслов - это интеллектуальная и художественная задача для теоретиков и исполнителей.

Упоминаний о работе над второй редакцией практически нет. Сочинение восстановлено композитором в 1923 г., но в 1924 г. еще проводилась корректура партитуры. «Тематический материал оставлен целиком, контрапунктическая ткань слегка усложнена, форма сделана стройнее, менее квадратной, а затем я работал над улучшением как фортепианной партии, так и оркестровой», - писал Прокофьев Н. Мясковскому в письме от 15 июля 1924 г. по поводу новой редакции концерта $[8, \text { с. 200] }]^{3}$.

Премьера концерта состоялась в Павловске, где солистом выступал сам С. Прокофьев. Мнение публики и критиков - подобно событиям премьеры Первого концерта - было в диапазоне от острого негатива до живого восторга. В 1914 г., когда Прокофьев познакомился в Лондоне с Дягилевым и показал свои сочинения, именно Второй фортепианный

\footnotetext{
${ }^{1}$ «Маддалена» (1911), «Игрок» (1915-1916), «Любовь к трем апельсинам» (1919), «Огненный ангел» (1919-1927).

2 «Сказка про шута, семерых шутов перешутившего» (1915).

${ }^{3} \mathrm{~B}$ дневниковых записях композитора встречаются намеки на отдельные детали замысла первоначальной версии музыкального материала концерта:

1. В финале концерта был эпизод с проведением темы первой части.

2. Прокофьев писал свой концерт одновременно с работой Мясковского над своей симфонической поэмой «Аластор»; впоследствии он заметил: «Первая тема “Аластор"» не имеет ничего общего с первой темой моего Концерта g-moll, а при разработке они становятся похожими» [17, с. 231].

3. По совету Стравинского Прокофьев разделил каденцию I части на две половины возгласом валторны (впоследствии эту переделку композитор отменил).
} 
концерт привел антрепренера в восторг ${ }^{1}$ и стал точкой отсчета в зарубежной карьере молодого композитора.

«Nothing that's worthwhile is ever easy» («То, что чего-то стоит, не дается легко», высказывание Николаса Спаркса) - создание концерта шло тяжело ${ }^{2}$. Бесспорно, работа над опережающим время произведением способствовала огромному росту Прокофьева. Второй концерт является своеобразной лабораторией, где молодой композитор ищет новые формы, которые будут служить выражению непростого замысла. «На этот раз, замечает И. Мартынов, - Прокофьев избрал редко встречающуюся форму четырехчастного концерта и трактовал каждую из частей свободно, поиному, чем это можно было видеть в большинстве инструментальных концертов» [12, с. 79]. Он трансформирует сонатную форму (первая часть - сонатная форма без репризы или трехчастная форма с чертами сонатности $^{3}$ ). В характере и тональном соотношении тематизма можно заметить нестандартную трактовку соответствия материалу главной, связующей и побочной партий.

Прокофьев считал, что его музыкальный язык сформировался к 2324 годам (что совпадает с окончанием работы над концертом). Именно во Втором концерте заметно обилие явных и не явных аллюзий-намеков, взаимодействие разных стилей, а жанровый синтез тематизма позволяет исполнителю активизировать отдельные признаки жанров. Музыкальными средствами Прокофьев создает систему «зашифрованных» знаков, которые помогают прочитать более глубокий уровень смысла произведения. Именно эта содержательность позволяет пианистам находить разные варианты художественной трактовки целого и выстраивать индивидуальные концепции.

\footnotetext{
${ }^{1}$ Сергею Павловичу сразу пришла идея поставить сцену на музыку концерта: чтобы Прокофьев играл, а на сцене танцевали. Дягилев обдумывал сферу образов - чтонибудь вроде Леля и Снегурочки, «только Леля не «мальчонку-пастушонка», а слегка гротескного, насмешливого» $[17$, с. 480]. Изначально Прокофьев не интересовался балетной музыкой и ожидал заказ на оперу. Однако благодаря этой встрече впоследствии было создано множество балетов («Сказка о шуте...», «Стальной скок», «Золушка», «Ромео и Джульетта» и т. д.), «Скифская сюита».

2 Также из дневников можно почерпнуть сведения о ходе работы: судя по всему, она шла тяжело: «Пытался сочинять Концерт, но устал, и ничего не выходило» [17, с. 180]; «Возился с темой ля-минор первой части. Первые два такта вышли ничего, но дальше сдвинуться не мог» [17, с. 182]; «Закончу ли его или помру со скуки?» [17, с. 188]; «Утром занимался g-moll'ным Концертом. Я в глубоком восхищении от него, но, Боже мой, когда же, наконец, я его закончу? [17, с. 238].

${ }^{3}$ Типичным для Прокофьева впоследствии станет использование сокращенной репризы (первая часть и финал концерта). Впервые этот прием композитор использовал в третьей фортепианной сонате (1917).
} 


\section{Концепции исполнителей}

Музыка Второго концерта для фортепиано с оркестром работает как зеркало, отражая внутреннее состояние слушателя и исполнителя. Также свой отпечаток на создании концепции оставляют возраст и жизненный опыт исполнителя.

Анализируя выбранные нами исполнительские версии, можно вывести два основных вектора мышления:

1. монументальность, масштабность, отстраненность, повествовательность (исполнение Н. Петрова и Б. Гилтбурга);

2. опора на характерные особенности тематизма, фантазийность, фантастичность, романтичность (исполнение В. Ашкенази и Ю. Ванг).

Очевидно, что пианисты по-разному трактуют образность концерта, создавая различные драматургические концепции трактовки целого. Это заметно на уровне темповых соотношений частей, проявляется в диалогическом взаимодействии партий солиста и оркестра в драматургически значимых моментах - следовательно, и в образном итоге трактовки сочинения. Так, версия Николая Петрова может быть названа рационально-драматичной, Владимира Ашкенази - лирико-драматичной, Юджи Ванг - субъективно-взолнованной, экспрессивной, Бориса Гилтбурга - лирико-драматичной и философичной.

Образно-смысловой потенциал концерта в большей мере заложен в тематизме драматургически значимых разделов первой, третьей и четвертой частей: жанровый синтез тем в партии пианиста позволяет исполнителю усилить черты одного жанра, несколько уводя в тень другие (естественно, это относится к музыкальному материалу не только солиста, но и цельной ткани сочинения). Во многом эти ключевые точки драматургии определяют образную направленность каждой из частей, а в финале - смысловой итог целого. Узловые моменты, выбранные для аналитического рассмотрения исполнительских версий:

- оркестровое вступление - секвенция терциями, аллюзия-цитата (Dies irae);

- главная партия (первая тема) - песня, декламационное начало;

- вторая тема главной партии первой части (завершающее построение) - декламационная основа, черты песни, колыбельной;

- каденция первой части; третья часть - тема вступления (basso ostinato, черты марша);

- четвертая часть, главная тема - пляска (позитивное прочтение усиление интонационной жанровости, образа массового действия, 
энергетической пульсации, негативное - механистичность, враждебность, образ негативной внешней силы);

- четвертая часть, побочная тема - колыбельная как символ прошлого, о котором вспоминают с горечью или нежностью (перекликаясь или контрастируя с первой главной партией в эпилоге первой части), или колыбельная, полная жизни и надежды.

«Гений, - замечает Ю. Лотман, - отличается от других одаренных людей высокой степенью непредсказуемости» [10, с. 226]. Исследователь концентрирует внимание на существовании текста в культурно-исторической динамике: «Меняется мир, вместе с ним меняется и человек <... $>$. Те, кто бывал в Эрмитаже и видел скульптуру Вольтера работы Ж.-А. Гудона, знают о ее удивительном свойстве. Когда вы обходите ее, у скульптуры меняется выражение лица. Вы видите, как Вольтер плачет, издевается, смотрит на мир трагически и задыхается от смеха. <..> Меняется наша точка зрения, и меняется лицо скульптуры. Точно так же, когда мы обходим мир, он меняется <..>. Любое сложное, богатое произведение искусства <..> обладает внутренней динамикой» [10, с. 226]. Нынешнее время ищет и открывает в музыкальном тексте Прокофьева новые смыслы.

\section{Анализ четырех исполнительских версий}

Проанализировав нотный текст концерта, мы пришли к выводу о многозначности авторского замысла, что позволяет пианисту выстраивать собственную концепцию сочинения. Сопоставление первой и четвертой частей способствует выводу о ведущей роли лирического начала: об этом свидетельствует соотношение главных образных сфер.

В первой части звучат две главные темы: одна (см. Пример № 1) - в высоком регистре, полна лиризма, повествовательности, света; вторая (см. Пример № 2) - ее противоположность, антагонист, в среднем регистре, мрачная и строгая. Образ первой части во многом зависит от того, как будет сыграна первая лирическая тема главной партии, наполненная ощущением простора - отстраненно, холодно (Н. Петров), задумчиво и нежно, или с пафосом - это окрашивает образность первой части романтической патетикой, близкой к скрябинской (Ю. Ванг, В. Ашкенази), или философской углубленностью (Б. Гилтбург). В эпилоге характер этой темы подытожит образ всей части и почти определит концепцию концерта: у Н. Петрова она останется неизменной - несломленной, в версии Ю. Вангнаполнится энергией, живой эмоцией, у В. Ашкенази - превратится в призрачную тень, воспоминание. Колокольность второй темы главной партии - один из важнейших смыслов-символов. Тема состоит из трех 
элементов различной жанровой основы: попевка в объеме тетрахорда, песня и колыбельная (см. Пример № 2).

Можно по-разному трактовать и тему вступления (см. Пример № 3). Начальные интонации напоминают тему смерти (Dies irae, см. Пример № 4) или тему судьбы (начало первой части Пятой симфонии Бетховена ${ }^{1}$ ).

Пример № 1

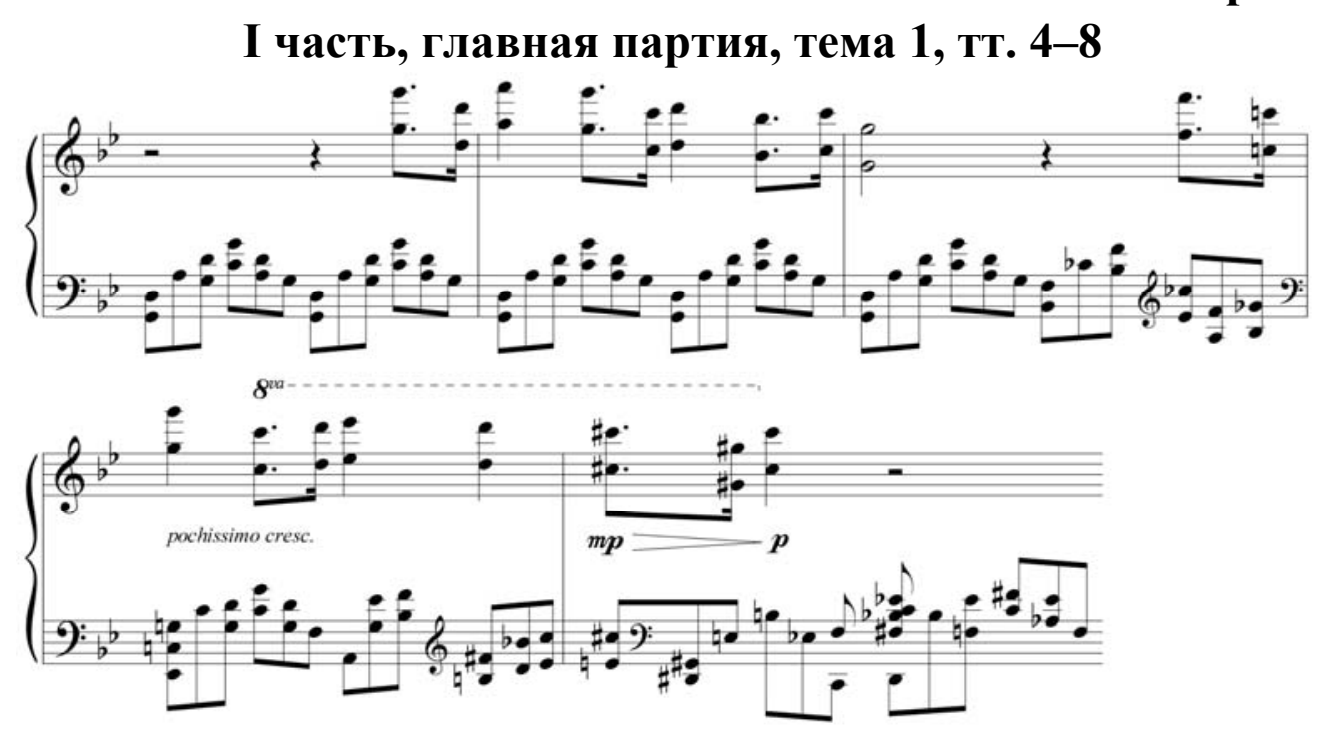

І часть, главная партия, тема 2, тT. 13-19

Пример № 2
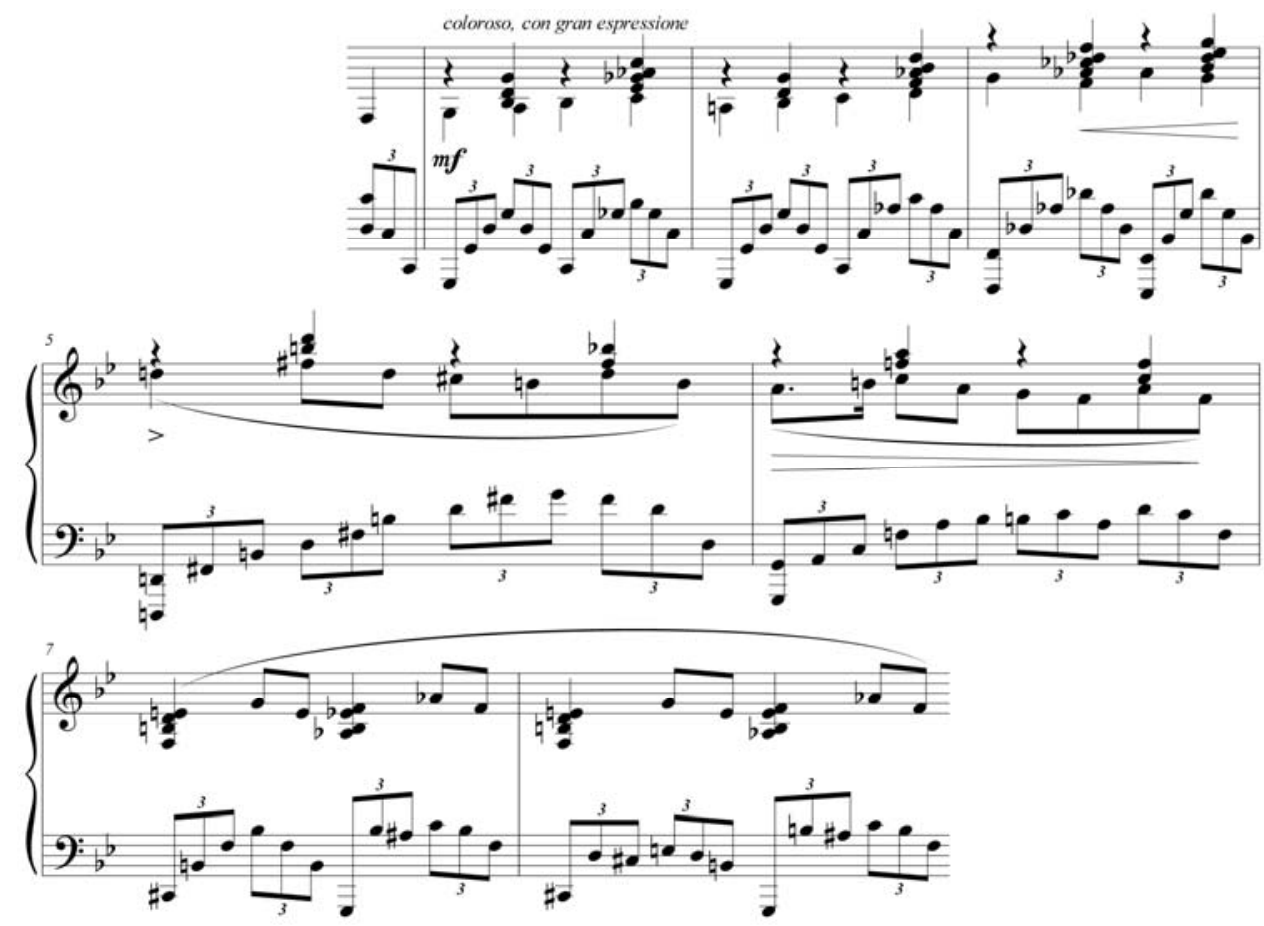

\footnotetext{
${ }^{1}$ Аллюзия же на знаменитый мотив Пятой симфонии Бетховена хотя и узнаваема, но не очевидна: в теме Бетховена - б.3+м.3, а в материале темы Прокофьева - м.3+м.3, кроме того, изменен ритмический рисунок. То есть аллюзия основана на воспроизведении интонационных очертаний темы Бетховена.
} 
Пример № 3

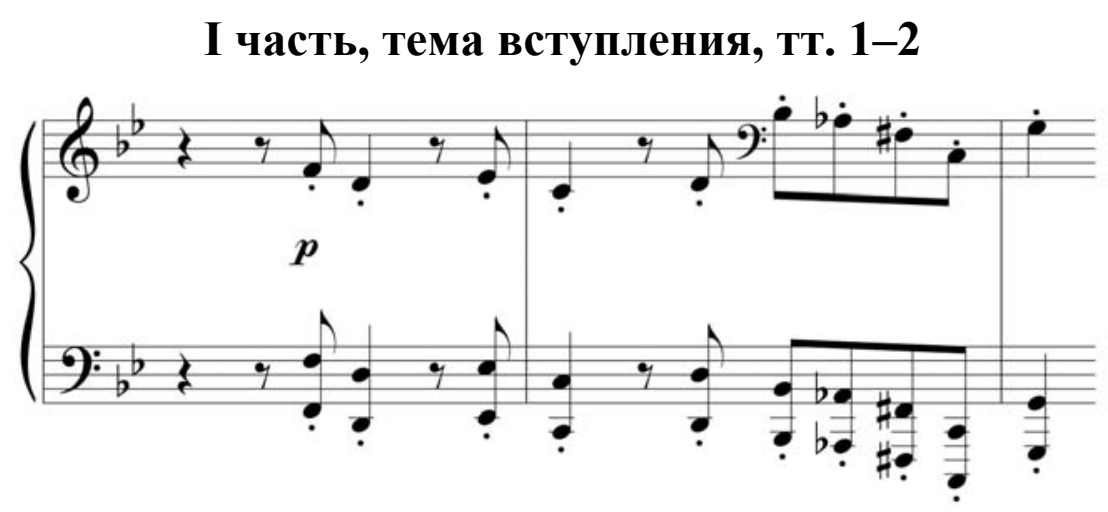

Пример № 4

Секвенция Dies irae

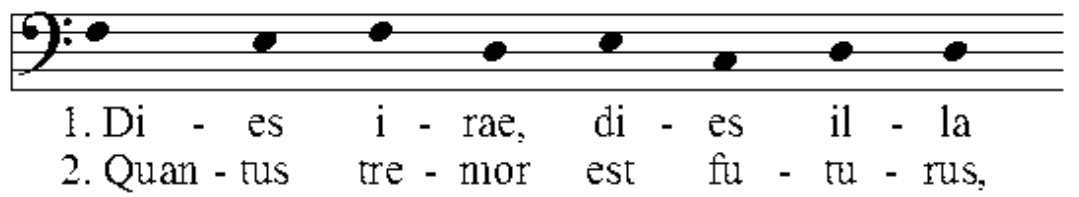

То, что о цитате-аллюзии Dies irae не упоминают исследователи, неудивительно: Прокофьев избегает прямого цитирования, а лишь оставляет контуры мелодии, которая в начале части не воспринимается как вестник беды. Однако в кульминационном разделе I части символические смыслы темы проявляются открыто: в грозном звучании труб тематический материал вступления предстает вполне определенной аллюзией к Dies irae, формируя область смыслов, апеллирующих к определенной семантике. Добавим еще один факт: в годы работы Прокофьева над концертом Мясковский писал свою вторую сонату для фортепиано с использованием прямой цитаты Dies irae, что косвенно не столько подтверждает естественность обращения Прокофьева к этой теме-символу, сколько объясняет его нежелание обеспечить очевидную ее узнаваемость.

Каденция (она же разработка) подобна накалу высочайших температур: это - момент противостояния света и тьмы (эпиграфа-вступления и двух главных тем), завязка конфликта: от исполнителя полностью зависит драматургия и равновесие сил в каденции. Н. Петров играет ее мощно, устойчиво, без внутреннего надрыва и внешней аффектации, прослушивая дифференциацию пластов фактуры. Солист сосредоточен на второй главной теме, а первая приравнивается к ней по общему тону-настроению. Предыкт к кульминации беспощадно ровен, создан чеканным ритмом в левой руке это еще сильнее подчеркивает ужасающий эффект, с которым врывается вступление меди. Здесь уже со всей очевидностью возникают аллюзии к теме Dies irae - семантика ее возникновения не вызывает сомнений: это драматическое столкновение, образ смерти. 
Иначе трактует музыкальную ткань Ю. Ванг: уже в переходе к разработке мы слышим фантастичность, которая вызывает ассоциации с образами Римского-Корсакова и Лядова (например, с «Волшебным озером»). Каденцию Ю. Ванг начинает туманно, издали, приглушенным звуком, поэтично и выразительно, особое внимание уделяя мелодизму в левой руке. Пианистка чередует образы-состояния: от скрябинской трансцендентности до неистовства, близкого стилю Стравинского, что художественно оправданно - после окончания второй редакции концерта Прокофьев пишет: «Все же мне Скрябин сейчас далек, и ближе мне Стравинский <..>. Идти в глубь мастерства или в ширь космоса? Скрябин или Стравинский? Оба, соединенные воедино!» [18, с. 231].

Б. Гилтбург, напротив, уводит каденцию в сферу романтического пафоса. Он показывает скрытые мелодические ходы, пропевая средние голоса и подголоски и подчеркивая полифоническое строение музыкальной ткани. Главная тема обретает пафосность звучания в момент торжества кульминации. Ярко и динамично пианист показывает столкновение тем, сохраняя их первоначальные образные характеристики.

«Я требую от сюжета, чтобы он сразу начинался драматическим действием», - писал Прокофьев [17, с. 515]. Это высказывание точно описывает оркестровое вступление III части концерта (Intermezzo) (см. Пример № 5). К музыке этой части часто применяется слово «гротеск». В книге статей Прокофьев замечает: «Гротесковую [линию творчества], которую иные стараются мне прилепить, [хотел бы] считать скорее как изгибы предыдущих линий [классической, новаторской, токкатной и лирической]. Во всяком случае, я протестую против самого слова “гротеск”, которое у нас затаскано до отвращения. Смысл французского слова grotesque при этом в значительной степени извращен. В применении к моей музыке я предпочел бы заменить его термином “скерцозность" или, если угодно, тремя русскими словами, дающими градации его: шутка, смех, насмешка» [20, с. 148-149]. В. Дельсон пишет, что музыка в основном, кроме среднего раздела, - мрачная, жутко фантастическая, порой зловещая, а также отмечает ассоциации исследователей Intermezzo с фресками Гойи [6]. 
Пример № 5

\section{III часть, Intermezzo, тема вступления, тт. 1-6}

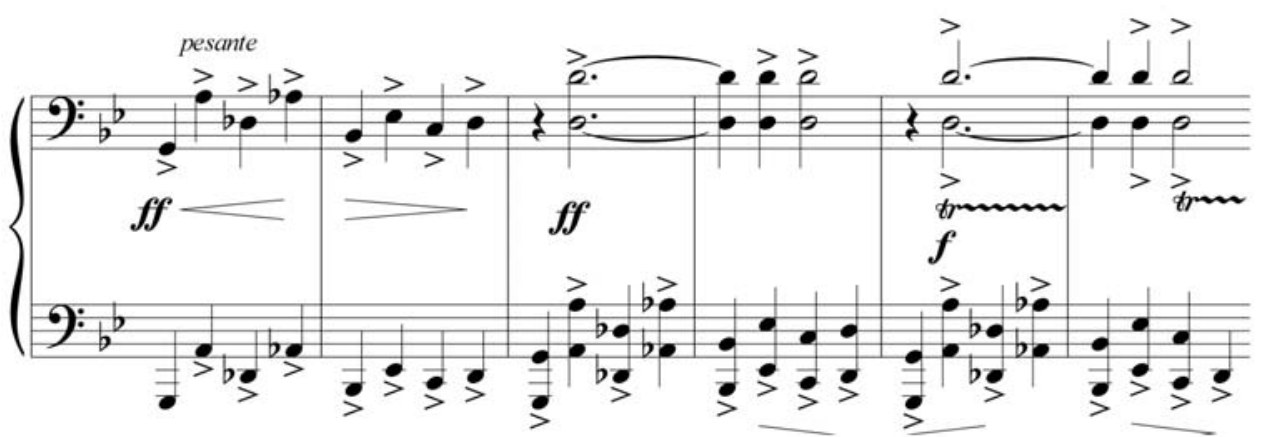

В версии В. Ашкенази ощутимо скифское начало, она воспринимается как предтеча суровой образности Монтекки и Капулетти из балета «Ромео и Джульетта»; это грозная, но не враждебная сила - в исполнении усиливается фантастичность тем, их гротескный (причудливый) характер. Максимально медленный темп возникает в версии Н. Петрова. Вступление темы - неуклюжее, тяжелое, зловещее. Ощущения фантастичности нет - это объективность, рациональность. Жанровые особенности тем из-за темпа и общности характера не просматриваются так ярко, как в предыдущей версии.

Иное состояние - калейдоскоп фантастических образов - создает Ю. Ванг. До конца части остается ощущение погружения в нереальный мир со сказочными преувеличениями, яркими красками. Концентрированный сосредоточенный образ создает Б. Гилтбург. Вступление пианиста - это негативная, злая тема, что подчеркивают завывающие пассажи. Создается зловещий образ тяжелого марша. Б. Гилтбург вызвучивает мелодические ходы в большей мере, чем иные исполнители. Кроме того, он формирует яркий контраст с лирической вариацией.

Колыбельная станет одним из главных образов-символов концерта: интонационный отголосок мотива второй главной темы (I часть) появится в IV части концерта, в побочной партии (см. Пример № 6), уже узнаваемым, отчетливым жанром колыбельной, а в разработке станет основой колокольных, богатырских, исполненных силы образов. Это еще один узловой момент, определяющий концепцию целого. В. Ашкенази исполняет тему колыбельной как воспоминание, сочувствующе, близко по характеру к завершению первой части. Он подчеркивает интонации русской песни (простота и ровность интонации, широкое дыхание, пластичность, эмоциональная сдержанность). У Н. Петрова побочная тема звучит полно, с горечью, в ней нет нежности, теплоты, преобладает мужское суровое начало. У Б. Гилтбурга тема полна одиночества и грусти, а у Ю. Ванг она выразительно-живая. 
Главная партия финала токкатна, механична, танцевальна, неистова. Материал танцевальной вариации будет включен в репризу четвертой части в комбинации с главной партией - это создает ощущение жизненной силы лирического образа. Также танцевальная вариация может считаться аркой между второй частью и финалом, объединяя их.

Еще один важный для Прокофьева образ-смысл прочитан Б. Гилтбургом - это колокольный звон в эпизоде каденции финала тепо mosso, который в его исполнении близок к бою часов (этот образ у позднего Прокофьева в балете «Золушка», Седьмой симфонии является символом времени, противоборства конечности бытия - вечности). Такие мелкие детали, зашифрованные в тексте, помогают исполнителям находить что-то новое в концерте, а произведению - звучать совершенно по-иному.

Пример № 6

IV часть, побочная партия, TT. 83-90
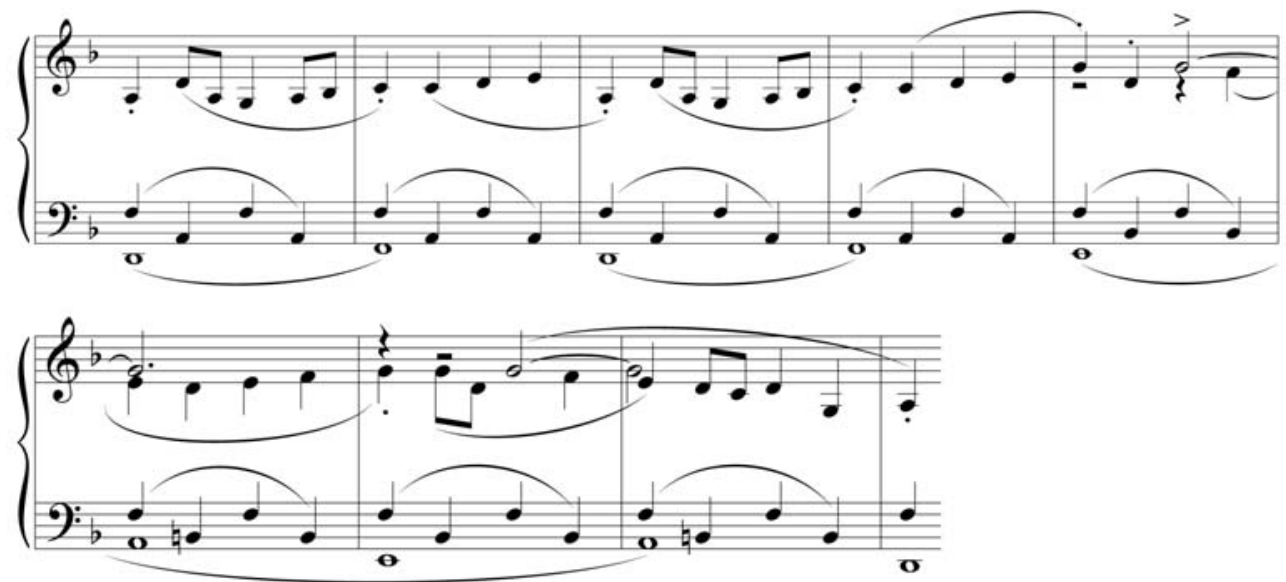

Таким образом, подтверждается пластичность музыкального материала концерта, а также выявляются черты монотематизма, присущие творчеству Бетховена и Листа. Три драматургические линии представляют собой основу концерта: лирическая (первая главная тема I части и колыбельная, IV часть), драматическая (темы вступления I и III частей), жанрово-бытовая / танцевальная (побочная тема I части, II и отчасти III части, а также главная партия IV части и танцевальная вариация в разработке).

Глиссандо по белым клавишам от $f$ к $c$ у солиста в мажоре в сочетании с восходящими интонациями и напором создает победоносное настроение. Последним тактом на звуках тоники без терцового тона С. Прокофьев подчеркивает открытость финала - отсутствие резюме. Уже почти сто лет пианистами вновь и вновь решается прокофьевский вопрос: что суждено теме «света» - побеждать или быть побежденной? Например, Б. Асафьев считал: «Концерт завершался триумфально. Смерть и тщетное беспокойство побеждены» [3, с. 57]. Это убедительно, ведь подтверждается 
самим прокофьевским стилем мышления - ироничным, проницательным, остроумным, интеллектуальным, полным жизнелюбивой энергии. Неслучайно А. Шнитке сказал о С. Прокофьеве: «Этот человек видел мир иначе и иначе слышал его. Темные бездны реального никогда не лишались в его представлении всепокоряющего солнца» [23, с. 211].

1. Алексеев А. Д. Русская фортепианная музыка конца XIX - начала XX века. Москва : Наука, 1969. 387 с.

2. Асафьев Б. В. Русская музыка XIX и начала XX века. Изд. 2-е / ред. Р. Г. Бутакова. Ленинград : Музыка, 1979. 344 с.

3. Вишневецкий И. Г. Сергей Прокофьев : монография / ред. А. В. Петров. Москва : Молодая гвардия, 2009. 703[1] с. (Жизнь замечательных людей, вып. № 1200).

4. Гаккель Л. Е. Фортепианное творчество С.С. Прокофьева. Москва : Государственное музыкальное издательство, 1960. 176 с.

5. Горобец А. С. Фортепианный концерт № 2 С. С. Прокофьева: образно-смысловые ресурсы произведения в нескольких исполнительских версиях : научноисследовательская работа на соискание научной степени магистра. / Киевский институт музыки им. Р. М. Глиера. Киев, 2018. 60 с.

6. Дельсон В. Ю. Второй концерт для фортепиано с оркестром [Электронный ресурc]. URL: http://www.belcanto.ru/prokofiev_concerto2.html (дата обращения: 10.05.2018).

7. Друскин М. С. Избранное. Монографии. Статьи. Москва : Советский композитор. $1981.336 \mathrm{c}$.

8. Кабалевский Д. С. С. Прокофьев и Н. Я. Мясковский. Переписка. Москва : Советский композитор, 1977. 493 с.

9. Либерман Е. Г. Творческая работа пианиста с авторским текстом / ред. Е. Либерман. Москва : Музыка, 1988. 236 с.

10. Лотман Ю. М. Воспитание души. Воспоминания. Беседы. Интервью. В мире пушкинской поэзии (сценарий). Беседы о русской культуре (телевизионные лекции) : сборник / Ю. М. Лотман. Санкт-Петербург : Искусство-СПб, 2005. 624 с.

11. Ляхович A. В. Прокофьев и Бетховен [Электронный ресурс] // ForumKlassika.Ru : веб-сайт. URL: http://www.forumklassika.ru/entry.php?b=8713\&bt=156458 (дата обращения: 13.03.2018)

12. Мартынов И. И. С.С. Прокофьев. Жизнь и творчество : монография. Москва : Музыка, 1974. 560 с.

13. Москаленко В. Г. Про специфіку музичної інтерпретації // Київське музикознавоство. Проблеми музичної інтерпретації : зб. ст. Вип. 2. Київ, 1999. С. 4-14.

14. Назайкинский Е. В. Логика музыкальной композиции. Москва : Музыка, 1982. 319 с.

15. Нестьев И. В. Жизнь Прокофьева : монография. 2-е перераб. и доп. изд. Москва : Советский композитор, 1973. $713 \mathrm{c.}$

16. Прокофьев С. С. Автобиография. / ред. Прокофьев С. С. Москва: Советский композитор, 1982. $600 \mathrm{c}$.

17. Прокофьев С. С. Дневник 1907-1918 гг. / ред. С. Прокофьев. Париж : DIAKOM, 2002. $787 \mathrm{c}$. 
18. Прокофьев С. С. Дневник 1918-1933 гг. / ред. С. Прокофьев. Париж: DIAKOM, 2002. $866 \mathrm{c}$.

19. Прокофьев С. С. Материалы, документы, воспоминания : сборник / сост., ред., примеч. и вступ. ст. С. И. Шлифштейна. Изд. 2-е, доп. Москва : Государственное музыкальное издательство, 1961. 708 с.

20. Прокофьев С. Статьи, интервью : сборник. Москва : Советский композитор, 1991. 285 с.

21. Сафонова Т. В. Творчество С. Прокофьева: анализ метафизической составляющей. : дисс. ... канд. искусствоведения : 17.00.09 / Саратовская государственная консерватория им. Л. В. Собинова, 2009. 192 с.

22. Холопов Ю. Н. Творчество Прокофьева в современном теоретическом музыкознании // С. С. Прокофьев. Статьи и исследования. Москва : Музыка, 1972. С. 299-332.

23. Ивашкин А. В. Беседы с Альфредом Шнитке // А. Шнитке. Слово о Прокофьеве : сборник. Москва : РИК «Культура», 1994. С. 207-214.

\section{References}

1. Aleksieiev, A. (1969). Russian piano music at the end of XIX century. Moscow: Nauka [in Russian].

2. Asafiev, B. (1979). Russian music of XIX and beginning of XX centuries. R. Butakova (Ed.). Leningrad: Muzyka [in Russian].

3. Vyshnevetskii, I. (2009). Sergey Prokofiev. A. Petrov (Ed.). Moscow: Molodaia Gvardiia [in Russian].

4. Gakkel, L. (1960). Piano oeuvre of S. S. Prokofiev. Moscow: Gosudarstvennoe Muzykalnoe Izdatielstvo [in Russian].

5. Horobets, H. (2018). Piano concerto № 2 by Sergey Prokofiev: contexts and semantics of musical composition in various performers' interpretations. Master's thesis. R. M. Glier Kyiv Institute of Music. Kyiv [in Russian].

6. Delson, V. (2014). Second piano concerto. [online] Available at: http://www.belcanto.ru/ prokofiev_concerto2.html [Accessed 10 May 2018] [in Russian].

7. Druskin, M. (1981). Selected. Monographs. Articles. Moscow: Sovetskii Kompozitor [in Russian].

8. Kabalevskii, D. (1977). S. S. Prokofiev and N. Y. Myaskovsky. Correspondence. Moscow: Sovetskii Kompozitor [in Russian].

9. Liberman, E. (1988). Creative work of pianist with author's text. E. Lyberman (Ed.). Moscow: Muzyka [in Russian].

10. Lotman, Y. (2005). Soul's education. Memoirs, conversations. Interviews. In the world of Pushkin's poetry (scenario). Coversations about Russian culture. Y. Lotman (Ed.). SaintPetersburg: Iskusstvo-SPb [in Russian].

11. Liakhovych, A. (2017). Prokofiev and Beethoven. [online] Available at: http://www. forumklassika.ru/entry.php?b=8713\&bt=156458 [Accessed 13 March 2018] [in Russian].

12. Martynov, I. (1974). S. S. Prokofiev. Life and art. Moscow: Muzyka [in Russian].

13. Moskalenko, V. (1999). About the specifics of the musical interpretation. Kyivske muzykoznavstvo, 2. pp. 4-14 [in Ukrainian].

14. Nazaikinskii, E. (1982). Logic of musical composition. Moscow: Muzyka [in Russian].

15. Nestiev, I. (1973). Life of Sergey Prokofiev. Moscow: Sovetskyi Kompozitor [in Russian].

16. Prokofiev, S. (1982). Autobiography. Moscow: Sovetskyi Kompozitor [in Russian].

17. Prokofiev, S. (2002) Diaries 1907-1918. S. Prokofiev (Ed.). Paris: DIAKOM [in Russian]. 
18. Prokofiev, S. (2002). Diaries 1918-1933. S. Prokofiev (Ed.). Paris: DIAKOM [in Russian].

19. Prokofiev, S. (1961). Materials, documents, memories. Second edition. S. Shlyfshtein (Ed.). Moscow: Gosudarstvennoe Muzykalnoe Izdatielstvo [in Russian].

20. Prokofiev, S. (1991). Articles, interviews. Moscow: Sovetskyi Kompozytor [in Russian].

21. Safonova, T. (2009). Oeuvre of S. Prokofiev: analysis of methaphysical component. $\mathrm{PhD}$ thesis. National Sobinov academy of music. Saratov [in Russian].

22. Kholopov, Yu. (1972). Oeuvre of S. Prokofiev in modern academic musicology. Moscow: Muzyka [in Russian].

23. Ivashkin, A. (1994). Word about Prokofiev. In: Conversations with A. Shnitke. Moscow: RIK Kultura [in Russian].

УДК 78.034:78.071 Монтеверді

DOI: https://doi.org/10.33643/kmus.2019.59.10

$$
\begin{array}{r}
\text { Вероніка Пкшкова, } \\
\text { аспірант кафедри історії світової музики } \\
\text { Національної музичної академії України ім. П. I. Чайковського } \\
\text { https://orcid.org/0000-0001-7875-2489 } \\
\text { veronika_peshova@ukr.net } \\
\text { Veronika Pieshkova, } \\
\text { Postgraduate at the Department of History of World Music, } \\
\text { Ukrainian National Tchaikovsky Academy of Music } \\
\text { https://orcid.org/0000-0001-7875-2489 } \\
\text { veronika_peshova@ukr.net }
\end{array}
$$

\section{ПРИНЦИПИ РОБОТИ 3 ПОЕТИЧНИМ ТЕКСТОМ У РАННІХ МАДРИГАЛАХ КЛАУДІО МОНТЕВЕРДІ (НА ПРИКЛАДІ МАДРИГАЛІВ ІЗ ПЕРШИХ ЧОТИРЬОХ КНИГ КОМПОЗИТОРА)}

У статті розглянуто мадригали 3 перших чотирьох Книг Клаудіо Монтеверді. Визначено специфіку образно-емоційної сфери, виявлено принципи втілення поетичного тексту в музичній тканині мадригалів. Здійснено підрядковий переклад українською мовою мадригалів «La vaga pastorella» 3 Першої книги (1587), «Non si levav'ancor» із Другої книги (1590), «Sovra tenere erbette» 3 Третьої книги (1592), «A un giro sol de, bell'occhi lucenti» з Четвертої книги (1603). На основі аналізу перелічених творів прослідковано процес зміни тематики поетичних текстів від Першої до Четвертої книг мадригалів Клаудіо Монтеверді.

Ключові слова: мадригал, слово, афект, бароко, втілення поетичного тексту, Монтеверді. 